\title{
Børnebøger i Danmark
}

af Vibeke Stybe

\section{Børnespejlet}

Iår er det 425 år siden, at det første skrift for børn udkom på dansk: Børne Speigel af Niels Bredal. Bogen udkom i Vejle i 1568, og ligesom den første danske ABC, man kender fra 1591, er den trykt hos Mads Vingaard.

I forordet henviser Bredal til den store humanist Erasmus af Rotterdams bog på latin om, hvordan børn skal "optugtes i Guds frygt og ærlige sæder." Men det er få, skriver Bredal, som holder deres børn i skole og endnu færre, som lader dem lære latin: " Der fore haffuer ieg (eders Børn besynderlige til tieniste) vdschreffuit paa Danske Rim nogen de fornæmmeligste Lærdomme ..."

Bredal blev, efter en tid at have været munk og skolemester, rektor for latinskolen i Vejle. Her har han bl.a. haft Anders Sørensen Vedel som discipel. Børnespeigel er ikke en oversættelse af Erasmus af Rotterdams bog; den adskiller sig bl.a. ved at være skrevet på vers. Nogen morskabsbog er den dog langt fra, den er en lærebog i, hvordan børn skal opføre sig. Lige fra morgen til aften er der regler for et dydigt levned. Om aftenen står der bl.a. (gengivet med vor tids retskrivning):

"Lig ret i sengen og ikke krum,

Fortrykke ej din staldbroder, giv ham rum.

Læg dig først på den højre side, det er sund,

Væn dig til at sove med åben mund.

Trænger dig en fjært? Lad hende gå,

Ellers må du forvente dig sygdom og skade. 
De lemmer naturen byder at hylle,

Dennom skal du skjule og dylle (dølge),

Vær som folk og ikke som fæ,

At hver mand haver ikke af dig spot og spe."

Belæring og gudsfrygtighed er indholdet i de tidlige bøger for børn, og illustrationerne er af religiøs art. I Børne Speigel er der kun to træsnit, som viser Jomfru Maria med barnet og Kristus på korset.

\section{Billeder og belæring}

En af de første bøger med mange træsnit er Orbis Pictus (Verden i billeder) af Johann Amos Comenius. Den udkom første gang i Danmark i 1672 med titlen: Den gandske Verden fuld af de Ting, som kand sees og sandses afmaled. Comenius ville belære børn med billeder og samtidig lære dem sprog. Den er tænkt som en skolebog; der er over 150 træsnit, som viser dagliglivet og det kulturelle liv på den tid. (Endog billedet af en sjæl kan man finde). Den fik stor betydning og en lang levetid. Goethe skriver f.eks., at den hørte til hans kæreste billedskatte.

Et utal af billeder findes også i En liden Billed-Bibel, der først udkom på tyski 1684. På dansk udkom den første gang i 1710. Bogen indeholder en lang række bibelske billedrebusser og smårim. Ikke mindre end 800 træsnit har børn kunnet studere. De små børn har kunnet bruge bogen som en slags pegebog, og de større har moret sig med at løse rebusser og lære rimene. Billederne spænder vidt: dyr, soldater, skøger, engle, den himmelske fader og satan, som man skal vogte sig for: "Vaager imod Satans Spil, Som Guds Børn opsluge vil."

Underholdende var også de mange illustrerede udgaver af Æsops fabler med "Nyttelige Dyds-Lærdomme" og "indrettet efter den Kiere Ungdoms Begreb."

\section{Oplysningstiden}

Med oplysningstiden begynder i slutningen af 1700-tallet børnebøger for 


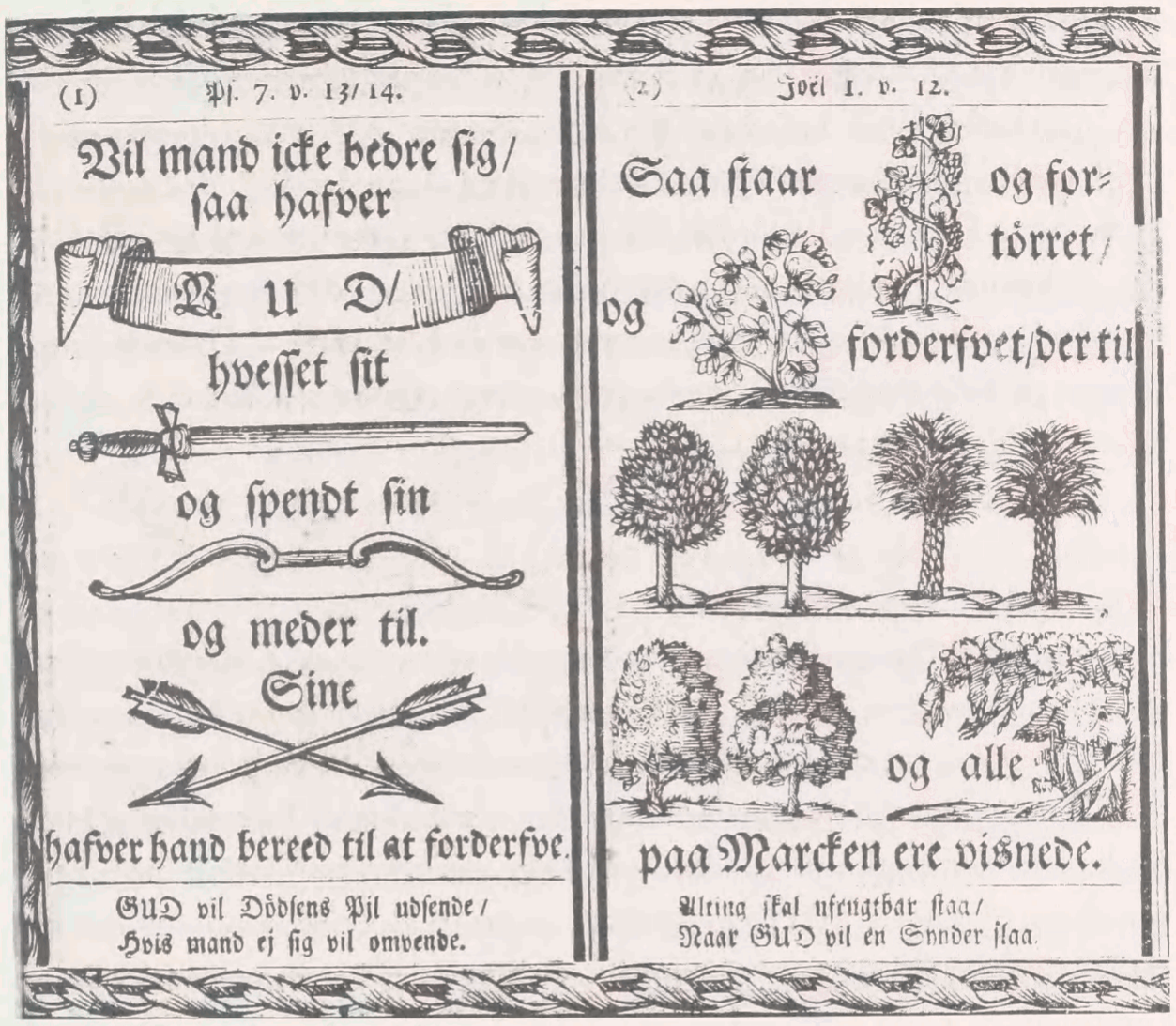

Opslag fra CCLII Udvalde og med 800 Billeder udlagde Bibelske Hoved-Sprog eller en saa kaldet liden Billed-Bibel benyttet til forfriskelse; og ungdommen til nytte at den derved må lære at nefne en hver ting med sit rette navn og uden nogen møje at erindre sig den hellige skriffts sprog. Oversat af det tydske tungemaal. Kbh. 1710.

alvor at dukke op. Mest berømt af alle er Campes Robinson den Yngre (tysk udg. 1779-80, da. udg. 1784-85) med to kobberstik. Titelkobberet viser en fader, omgivet af lyttende børn. Kobberstikkunstneren Daniel Chodowiecki lavede her et portræt af Campe som den fortællende fader, der moraliserer og samtaler med børnene, mens han fortæller den spændende historie.

I Danmark gjorde enkelte kobberstikkere sig gældende; men kun få inden for børnelitteraturen, og da ofte anonymt.

Oversættelser og efterligninger af udlandets bøger dominerede langt ind i 1800-tallet. Man skal lede længe efter originale danske børnebøger, og alt stof for børn betragtedes som fællesgods, man frit kunne benytte.

De fleste af tidens børnefortællinger handlede om uskyldsrene dydsmønstre til efterfølgelse og afskyvækkende skræmmebilleder til advar- 
sel. De bar titler som Tag dig i Agt! eller slet og ret Ulykkes-Historier for Børn. Her indtræffer ulykken som en rimelig straf for ulydighed.

Naturhistorisk belæring gik ofte side om side med moraliserende småfortællinger og samtaler. En lille børnebog, der må være helt dansk er O. Buchholms En Faders Vandring med sine Børn fra Kjøbenhavn til Brede (1817). Den er forsynet med otte håndkolorerede kobberstik, og børnene orienteres her på en underholdende måde i naturhistorie og botanik. - De danske bøger i denne periode er som regel beskedne i udstyr og bærer præg af de dårlige tider, der herskede i landet.

\section{H.C. Andersen}

På ét punkt har Danmark dog sat sig originale og varige spor i den internationale børnelitteratur. Da H.C. Andersen i 1835 udgav sit første hefte Eventyr, fortalte for Børn, var der kun få, der anede, at dette var noget ganske specielt.

Eventyrforskningen, især brødrene Grimm, havde vist vejen for H. C. Andersen, der begyndte med at genskabe eventyr, han havde hørt i sin barndom: Fyrtøjet, Lille Claus og Store Claus m. fl. Folkemindeforsker var H.C. Andersen ikke, men han fortalte eventyr på sin egen helt specielle og humoristiske måde, og han digtede også nye eventyr. Han står i dag som en af de allerstørste fortællere og er kendt over hele verden.

Det var i Tyskland i 1848, at et bind af hans samlede eventyr udkom første gang med illustrationer af Vilhelm Pedersen. Først året efter udkom eventyrene med de kendte og elskede illustrationer på dansk.

Eventyr havde for alvor holdt deres ind tog i børnelitteraturen i forrige århundrede, hvad enten det var bearbejdede folkeeventyr eller kunsteventyr.

H.C. Andersen havde sans for børnelitteratur. Interessant er det, at han i 1847 har købt den første danske udgave af Den store Bastian, som i de første udgaver hed Vær lydig! H. C. Andersen købte denne epokegørende billedbog til "Lille Anna og Ingeborg, de Smaabørn af Lind og Louise". Der er en morsom dedikation i bogen med et lille vers af H.C. Andersen. På omslaget har de collinske børnebørn skrevet "ÆV!" De forærede senere bogen til Odense Museum. 


\section{Klassiske billedbøger}

Den store Bastian, som er skrevet af den tyske læge, Heinrich Hoffmann, blev straks en enorm succes. Den udkom i Tyskland i 1845 med titlen: Der Struwwelpeter, den figur, som på dansk fik navnet "Fugleskræmslet", hvorfra man bl.a. husker stroferne: "Hvo ej rede la'r sit Haar, sine Negle skjære. Han til Spot som Konrad staaer, Øgenavn maa bære." - Den danske oversætter, Simon Simonsen, tilføjede tre helt nye danske historier: Historien om Speiledukken, Historien om Rikke Slikmund og Hanne i Maanen. Hvem, der har illustreret dem og overført Hoffmanns tegninger, vides ikke.

En anden dansk børnebogsklassiker blev Fabler for Børn. Af H.V. Kaalund og J.T. Lundbye (1844). Det er ikke æsopiske fabler, men små børnedigte, der fortrinsvis handler om dyr. Kaalund og Lundbye blev inspireret af Joh. Wilh. Hey's tyske børnefabler (1833-34) med Otto Speckters illutrationer. Lundbyes illustrationer gjorde Kaalunds digte til en ægte dansk børnebog. Her finder man den danske bondegård, en dansk milepæl på vejen og en kæmpehøj på marken. - Men bogen var uden farver og solgte dårligt. Derfor lod forlæggeren restoplaget håndkolorere, og Lundbye måtte selv kolorere et eksemplar som forlæg. I et brev skriver han, at det var et grueligt hoveriarbejde. - Senere blev digtene læsebogsstof, og mange børn har kunnet dem udenad.

Hvorledes Dagen gaaer for lille Lise af Lorenz Frølich blev trykt første gang i Paris, hvor Frølich boede i mange år og udgav en lang række billedbøger (ca. 100) sainmen med den franske forlægger P.-J. Hetzel. Kun tre blev udgivet på dansk. La journée de Mlle Lili blev en stor succes og udkom i 1862 - først året efter på dansk. Den korte tekst, der ledsager billederne, er skrevet af "En Fader", et pseudonym for P.-J. Hetzel. Tegningerne viser Frølichs egen lille datter og var oprindelig skitser, som han sendte hjem som julegave til sin mor. I 1889, hvor Frølich boede i Danmark, udkom billedbogen i en helt ny udgave og trykt i farver. Den versificerede tekst blev skrevet af Ernst v. der Recke.

Peters Jul fra 1866 fik stor kulturel betydning. Der var ikke faste juletraditioner i Danmark på den tid, og ordet julemand kendtes ikke. Den lille, beskedne julebog har en delvis koloreret billledfrise, der er tegnet af Pietro Krohn og Otto Haslund. Versene er af Johan Krohn. Det har vist sig, at omslaget er kopieret efter tyskeren Moritz von Schwinds billedark om den uvel- 
komne Hr. Vinter, hvis skæg er frosset til istapper. Heller ikke bogens specielle form, skåret til efter "julefars hætte", er original, men kopieret efter en lille bog, der udkom på engelsk i Tyskland ca. 1859. - Brødrene Krohns forældre havde opholdt sig en årrække i Tyskland, og de juleskikke, de de lærte at kende, bragte de med hjem til Danmark. Hos familien Krohn blev julen fejret efter alle kunstens regler. - Bogen lå færdigtrykt i 1865; men blev først solgt ved juletid næste år. Brødrene Krohn var flove over "dens Kjælderudseende", men gav alligevel til sidst deres samtykke, så den kunne sælges.

Omend 1.udg. af Peters Jul har et fremmedartet udseende, er indholdet dansk. I 1870 blev Peters Jul til en statelig billedbog. Teksten blev udvidet, og Pietro Krohn lavede helt nye illustrationer i træsnit. Først fra nu af blev den alle børns julebog og en elsket klassiker, der er blevet moderniseret og genillustreret flere gange. Med Frants Henningsens illustrationer i $1889 \mathrm{blev}$ den trykt i farver. Sidst blev Peters Jul i 1942 illustreret af Herluf Jensenius.

Den farvetrykte billedbog havde for alvor holdt sit indtog. Ikke altid var farvetrykket lige vellykket; men i Aarets tolv Maaneder (1866), der blev tegnet af C. Aagaard, B. Olsen og V. Rosenstand, er farvetrykket fint udført hos Em. Bærentzen og Co. De tolv billedsider viser, hvad der karakteriserer hver måned. I april er der flyttedag, og "med Sengehalm man raaber". December-billedet viser fem situationer fra julen. Juletræet tændes, og gaverne bringes ind i stuen. Grangrene slynger sig ind imellem billederne.

Forlæggerne kappedes nu om at udgive farvestrålende billedbøger, både af danske kunstnere, men også importerede billedbøger, ofte i dårligt farvetryk. Det var især folkeeventyrene, der måtte holde for, og bøgerne vakte undertiden mishag. Danske billeder til danske børn var parolen i 1880'erne.

To forlæggere, Ernst Bojesen og Alfred Jacobsen, gjorde en stor indsats. Billedtryk var deres speciale, og de kaldte deres forlag for kunstforlag. De var drevne forretningsmænd og kappedes om børnenes gunst. Ernst Bojesen udgav fra 1884 Børnenes Juleroser, og fra 1887 fulgte Alfred Jacobsen efter med Børnenes Julegave i samme stil. Alfred Jacobsen udgav også fra 1890 serien Danske Billedbøger for at fortrænge "de Masser af slette Billedbøger, som aarlig tilføres vort Land, og som kun ødelægger Børnenes Smag og Forstaaelse." Dette nationale initiativ blev hilst med begejstring.

Også den illustrerede børnefortælling og børneroman vandt frem. I 
Chr. Erichsens serie Børnenes Bogsamling fra 1896 er bøgerne rigt illustreret af danske illustratorer. Poul Steffensen var Chr. Erichsens foretrukne illustrator, og han indledte serien med illustrationer til Robinson Kruse. - "Illustreret af danske Kunstnere" står der ofte på titelbladene til eventyr-samlinger, serieudgivelser, samlinger af småfortællinger og læsebøger.

I pragtudgave udkom Carit Etlars Gjøngehøvdingen og Dronningens Vagtmester, der indeholder 216 illustrationer af Poul Steffensen.

\section{0-tallet}

Louis Moe blev børnenes illustrator frem for alle andre. Han var født i Norge, men virkede i Danmark, hvor hans utallige illustrationer findes overalt: i billedbøger, eventyrsamlinger, børneromaner, skolebøger, børneblade m.m.

En række af hans billedbøger blev epokegørende, og sammen med den svenske illustrator, Elsa Beskow, dominerede han billedbogsmarkedet i et halvt århundrede. Han var præget af jugendstilen i sine tidlige billedbøger, f.eks. i Blomsternes Bog. Hans domæne var personificerede blomster og dyr, skovens træer og det farlige "troldtøj". Louis Moe var allerede i 1891 begyndt at illustrere for Alfred Jacobsen, og hans illustrationer til gamle danske Rim og Remser slog straks hans navn fast.

Foruden Louis Moe havde bladtegneren Alfred Schmidt sin personlige streg og har illustreret mange billedbøger og børnefortællinger. En fuldtræffer var Flugten til Amerika (1900), der oprindelig var en række akvareller til Chr. Winthers vers fra 1830 'erne. Det er en stille dansk idyl, som Alfred Schmidt bygger videre på. Den barske realistiske baggrund for flugten til Amerika mærkes ikke.

Udviklingen i vort eget århundrede har været forrygende, ikke mindst på grund af tegneseriens udvikling, hvor Amerika førte an. Med maleren og vittighedstegneren Robert Storm Petersen fik Danmark dog sin egen tegneseriekunstner i verdensformat. Serien om Peter og Ping startede i 1912 i B.T., og den fandt hurtigt vej til de andre nordiske lande og senere endnu videre. Storm P. illustrerede også ca. 15 billedbøger og desuden mange andre børneog skolebøger. Den klassiske Spørge Jørgen af Kamma Laurents illustrerede han i 1944.

Behovet for udenlandsk børnelitteratur - når man undtager tegnese- 


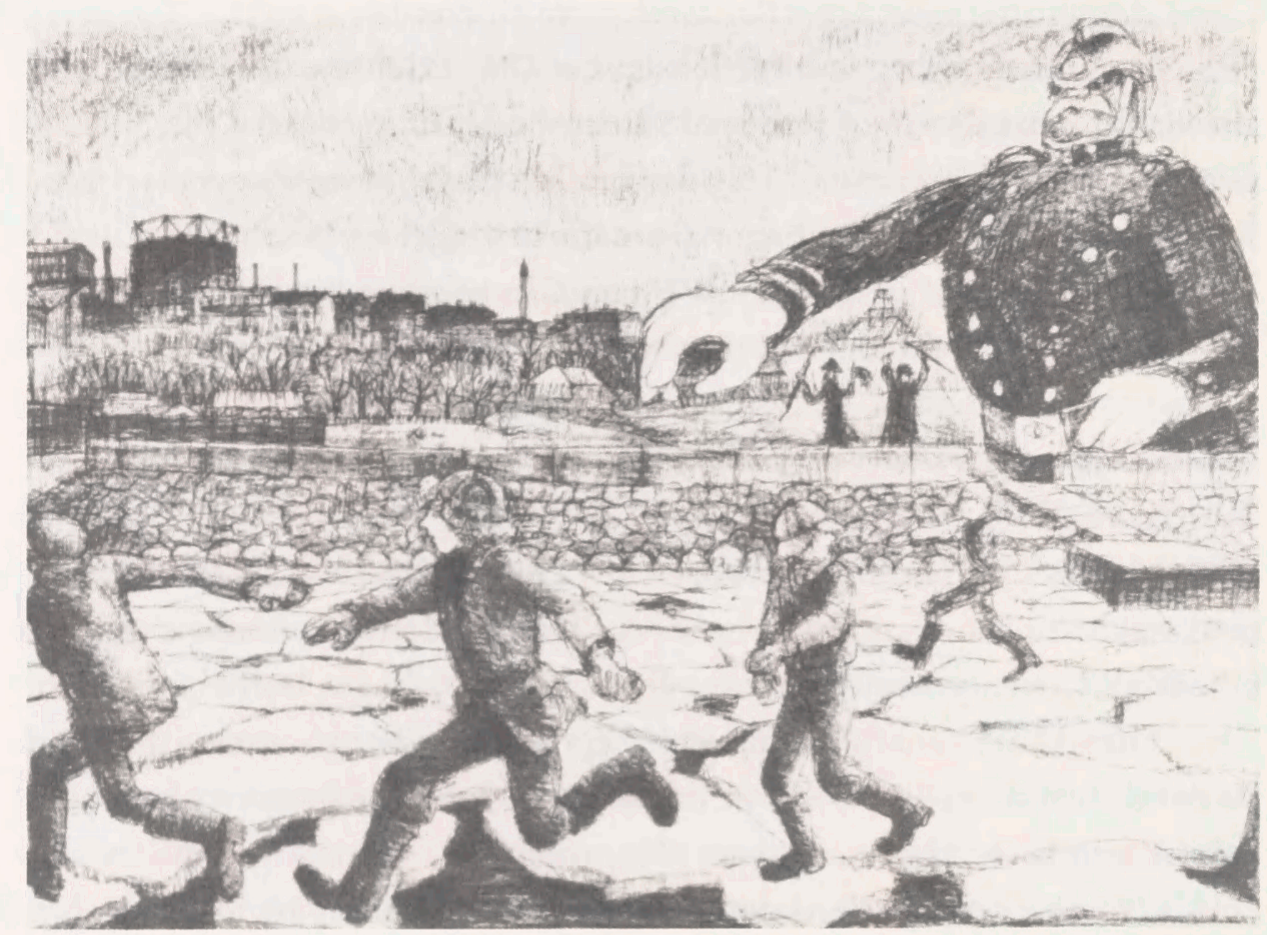

Smådrenge i løb på isen på Svanemøllebugten ca. 1931 for at undgå en betjent, i Ib Spang Olsens erindrende streg i hans bog Lille dreng på Østerbro, 1980 for, som han skriver: "Man kom nødig nærmere end tyve meter på en betjent, og derfor måtte vi løbelængere ud, hvor der var mere vand mellem flagerne, og betjenten nok inden længe måtte opgive".

rier og anden billig import - var ikke så stort i første halvdel af dette århundrede. Kun de allerstørste internationale successer nåede frem. 2. verdenskrig satte yderligere gang i den danske produktion, og en række forfattere og kunstnere skabte uforglemmelige bøger i perioden 1930-50.

\section{Nye impulser}

Der sker i denne periode en fornyelse; en ny stil og nye emner, især pædagogiske, dukker op. I 1932 vistes hos Illum en udstilling med børnebøger fra Sovjet, og den fik betydning for flere danske kunstnere, bl.a. for Arne Ungermann, Hans Scherfig og Aage Sikker Hansen. Plakatkunsten kom også til at præge adskillige billedbøger. Nævnes kan Toget (1936), illustreret af Arne Ungermann til vers af Harald $\mathrm{H}$. Lund. De store flotte farvebilleder er hver for sig en smuk plakat. Især Ungermanns samarbejde med Jens Sigsgaard 
blev meget frugtbart. Deres største succes blev Palle alene i verden (1942), der udkom i ca. 30 lande. Den er blevet genoptrykt og ændret flere gange, mest radikalt i 1974, hvor Ungermann fik lejlighed til helt at omtegne den efter datidens forhold. Busser afløste sporvogne, Palle blev iført cowboybukser osv.

Billedmageren Egon Mathiesen hører også til de nyskabende og internationalt kendte billedbogsskabere. Han overførte det abstrakte i sin malerkunst til sine billedbøger og skabte en hel ny genre. Mis med de blå øjne (1949) nåede ud til så fjerne lande som Kina. Af hans mange andre billedbøger blev især Aben Osvald (1947) populær i Sovjet.

Efter anden verdenskrig udviklede samtrykket sig hektisk. Der skabtes en masseproduktion, hvor Danmark også kom med. Carla og Wilhelm Hansens Rasmus Klump-serie startede i 1952, og der er nu mere end 30 forskellige titler.

I dag er de to største navne i dansk billedbogskunst: Ib Spang Olsen og Svend OttoS. De har begge modtaget den internationale børnebogspris, H.C. Andersen-medaljen, som siden 1956 er blevet uddelt af IBBY (International Board on Books for Young People). Først fra 1966 kom også en illustratorpris. I 1972 modtog Ib Spang Olsen prisen - i 1976 Svend Otto S.

I 1976 fik Cecil Bødker H.C. Andersen-medaljen for sin første Silas-bog. Det er nemlig ikke alene på illustrationskunstens område, at Danmark gør sig gældende. I forhold til landets størrelse udkommer et stort antal danske børnebøger i udlandet. På internationale messer er interessen for dansk børnelitteratur blevet større og større. - År for år får vi naturligvis også flere oversættelser fra andre lande.

Det internationale miljø omkring børnebøger har haft stor indflydelse i Danmark, og vi har også selv bidraget på dette kulturelle område, som burde værdsættes langt mere, end det er tilfældet. 